DEPARTMENT OF THE INTERIOR

UNITED STATES GEOLOGICAL SURVEY

PREPARED IN COOPERATION WITH THE

STATE OF CONNECTICUT

GEOLOGICAL AND NATURAL HISTORY SURVEY

\title{
AEROMAGNETIC MAP OF THE LITCHFIELD QUADRANGLE, LITCHFIELD COUNTY, CONNECTICUT
}

GEOPHYSICAL INVESTIGATIONS

MAP GP-843

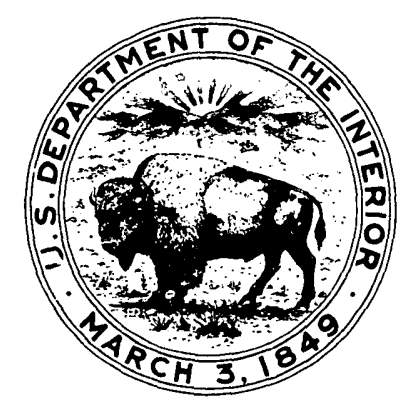

PUBLISHED BY THE U. S. GEOLOGICAL SURVEY

WASHINGTON, D.C. 20242 